\title{
EMISI DAN ABSORPSI GAS METANA PADA SISTEM PENANAMAN PADI DI AREA TANAH SAWAH
}

\author{
Marniati Salim ${ }^{1}$, Hiyal Faizah ${ }^{1}$, I Made Sudiana² \\ ${ }^{1}$ Laboratorium Bioteknologi, Jurusan Kimia, FMIPA, Universitas Andalas \\ ${ }^{2}$ Laboratorium Ekologi dan Fisiologi, Mikrobiologi LIPI, Cibinong \\ Email: bundosalim@yahoo.com
}

\begin{abstract}
To know there are emission and methane absorption, research was conduted by measuring directly gas methane at the rice field and absorption with metanotroph bactery using chromatography gas. From the research, we know that there is methane gas emission at the rice field. Watery land condition, emit methane gas $(2,309 \mathrm{mg} / \mathrm{L})$ larger than not watery land $(0,059 \mathrm{mg} / \mathrm{L})$. At the same time and paddy age is 2 month, it also emit larger methane gas $(1,809 \mathrm{mg} / \mathrm{L})$ than 1 month age paddy $(1,758 \mathrm{mg} / \mathrm{L})$ and without paddy $(0,697 \mathrm{mg} / \mathrm{L})$, whereas for methane absorption at land sample T0, T1, T2, T3, shows that with fertilizer given can increase the reduction of injected methane gas.
\end{abstract}

Keywords: Absorption, Metanotroph bacteria, Methane gas emission

\section{DAFTAR PUSTAKA}

1. IPCC, The Physical Science Basis. Contribution of Working Group I to the Fourth Assessment Report of the Intergovernmental Panel on Climate Change, http://www.IPCC.com, 2007.

2. IRRI, Rice Production, Methane Emission, and Global Warming. Los Banos, Laguna, Philippines, http://www.IRRI.com, 2000.

3. AJB. Zehnder, and Stumm W, Geochemistry and biogeochemistry of anaerobic habitats. In Untung Sudadi, Produksi Padi dan Pemanasan Global:
Tanah Sawah Bukan Sumber Utama Emisi Metana, 1988.

4. F. N. Ponnamperuma, Chemical kinetics of wetland rice soils relative to soil fertility. In IRRI, Wetland Soils: Characterization, Classification, and Utilization, Proc. IRRI Workshop, IRRI, Los Banos, Philippines, 59-94, 1985.

5. L. Solorzano, Determination of ammonia in natural waters by the phenolhypochlorite method, Limno. Oceano, 14: 799, 1969.

6. Y. Ikawati, dan S. Imade., Jurus Baru Melumat Metana, Kompas Ilmu Pengetahuan dan Teknologi, 2010. 